\title{
The importance of technological anxiety for the digital transformation of industrial processing companies in Poland
}

\author{
Michał Młody \\ Poznań University of Economics and Business
}

\author{
Adam Weinert \\ Poznań University of Economics and Business
}

\section{Introduction}

Industry 4.0 (otherwise known as the Fourth Industrial Revolution, Revolution $4.0)$ is a topic that is increasingly being addressed not only in business circles and economic policy but also in scientific discourse, as evidenced by the rapidly growing number of publications in renowned scientific journals 1 . In the era of change brought about by this digital transformation of industry, companies are facing the challenge of skillfully implementing and effectively using machines and advanced ICT technologies such as progressive robotisation, artificial intelligence, the Internet of Things, intelligent sensors and transmitters, Big Data ${ }^{2}$.

1 V. Alcácer, V. Cruz-Machado, Scanning the Industry 4.0: A Literature Review on Technologies for Manufacturing Systems, "Engineering Science and Technology an International Journal” 2019, vol. 22(3), pp. 899-919; C.O. Klingenberg, M.A.V. Borges, J.A.V. Antunes Jr., Industry 4.0 as a data-driven paradigm: a systematic literature review on technologies, "Journal of Manufacturing Technology Management" 2019, http://doi.org/10.1108/jmtm -09-2018-0325; J.M. Müller, Industry 4.0 in the Context of the Triple Bottom Line of Sustainability: A Systematic Literature Review, [in:] C. Silvestri, M. Piccarozzi, B. Aquilani (eds), Customer Satisfaction and Sustainability Initiatives in the Fourth Industrial Revolution, IGI Global, Hershey 2020, pp. 1-20, http://doi.org/10.4018/978-1-7998-1419-1 (accessed: 8.01.2020).

2 K. Schwab, Czwarta rewolucja przemystowa, transl. A.D. Kamińska, Wydawnictwo Studio EMKA, Warszawa 2018. 
Some impact of digital transformation on the functioning of companies and their environment, including, in particular, suppliers, manufacturers, business partners and customers, is inevitable, resulting in new value chains and business models ${ }^{3}$. Organisational and technological changes are driven by the evolution of customers' needs and the requirements of mass personalisation ${ }^{4}$. The multifaceted impact of the Industry 4.0 concept opens new areas of research for researchers. Areas however, due to limited access to information on the background and consequences of the digital transformation process, which require a thorough and careful exploration. The article assumes that the identifying feature of the concept of Industry 4.0 is related to the integration of people and machines, along with advanced information and communication technologies, enabling real-time interaction between key components of a company ${ }^{5}$.

Adopting technology 4.0 requires a systemic view on the functioning of the entire company6 ${ }^{6}$ Scientific studies on Industry 4.0 focus mainly on the very scope of the concepts, objectives and potential beneficial results ${ }^{7}$. At the same time, there is a research gap in the literature concerning the barriers to digital transformation $^{8}$. The aim of the article is to determine the significance of technological anxiety for the digital transformation of production companies operating in the Polish industrial processing sector. The results of the empirical research conducted cover six dimensions of technological anxiety, the significance of which was presented on the basis of the age of companies, the size of employment and the phase of transformation they are in.

3 L. Herbert, Digital Transformation: Build Your Organization's Future for the Innovation Age, Bloomsbury, London 2017.

4 K. Nosalska et al., Industry 4.0: coherent definition framework with technological and organizational interdependencies, "Journal of Manufacturing Technology Management” 2019, https://doi.org/10.1108/JMTM-08-2018-0238 (accessed: 8.01.2020).

5 M. Mtody, A. Weinert, Industry 4.0 in Poland: A Systematic Literature Review and Future Research Directions, [in:] A. Zakrzewska-Bielawska, I. Staniec (eds), Contemporary Challenges in Cooperation and Coopetition in the Age of Industry 4.0: 10th Conference on Management of Organizations' Development (MOD), Springer International Publishing, Cham 2020, pp. 43-71, http://doi.org/10.1007/978-3-030-30549-9_2

6 Technologies 4.0 belong to the open set because of the combinations of solutions and their derivatives permanently developed by manufacturers and users. A wider range of technologies 4.0 is presented by e.g. M. Młody, A. Weinert, Industry 4.0 in Poland...; K. Nosalska et al., Industry 4.0...

7 M. Młody, Lęk technologiczny jako patologia organizacyjna w dobie czwartej rewolucji przemysłowej, "Studia i Prace Kolegium Zarządzania i Finansów” 2019, no. 175, pp. 129-144.

8 D. Horváth, R. Szabó, Driving forces and barriers of Industry 4.0: Do multinational and small and medium-sized companies have equal opportunities?, "Technological Forecasting and Social Change” 2019, vol. 146(C), pp. 119-132. 


\section{The multidimensionality of technological anxiety in the industrial processing sector - hypothesis development}

\section{Industry 4.0 and technological anxiety}

The term Industry 4.0 is derived from the German initiative 'Industrie 4.0', developed in 2011 and aimed at strengthening the competitiveness of the manufacturing industry ${ }^{9}$. Despite the growing number of publications, the concept of Industry 4.0 has not yet been clearly defined ${ }^{10}$, and therefore it has been used in research to a limited extent. Studies (especially those made by practitioners) emphasise the benefits of the implementation of Industry 4.0 solutions, supported by examples of successfully completed projects. The spread of technology is driven by the promoted vision of a highly beneficial reality for consumers/recipients of products and services.

The dynamic development of modern technologies means that both the companies themselves and society as a whole are forced to constantly adapt to this new reality. At the same time, the barriers and problems that companies face in the process of digital transformation in the era of Revolution 4.0 are addressed to a limited extent. Modern technologies may be perceived as a threat to a set of established norms and patterns of behaviour, bringing negative emotional reactions, anxiety and fear ${ }^{11}$. Consulting companies, among others: $\mathrm{PwC}^{12}, \mathrm{McKinsey}^{13}, \mathrm{BCG}^{14}$, clearly indicate the uncertainty among company managers concerning what the

9 H.S. Kang et al., Smart manufacturing: past research, present findings, and future directions, "International Journal of Precision Engineering and Manufacturing - Green Technology" 2016, vol. 3(1), pp. 111-128; A. Issa et al., Industrie 4.0 roadmap: Framework for digital transformation based on the concepts of capability maturity and alignment, "Procedia CIRP" 2019, no. 72, pp. 973-978.

10 K. Nosalska et al., Industry 4.0...

11 M. Martínez-Corcoles, M. Teichmann, M. Murdvee, Assessing technophobia and technophilia: Development and validation of a questionnaire, "Technology in Society" 2017, no. 51, pp. 183-188.

12 PwC, Przemyst 4.0, czyli wyzwania wspótczesnej produkcji, PwC Polska, 2017, https://www .pwc.pl/pl/publikacje/2017/przemysl-4-0.html (accessed: 12.01.2020).

13 McKinsey, Industry 4.0. Capturing value at scale in discrete manufacturing, 2016, https://www .mckinsey.com (accessed: 8.01.2020).

14 BCG, Przemyst 4.0 PL. Szansa czy zagrożenie dla rozwoju innowacyjnej gospodarki?, Boston Consulting Group, Boston 2016, https://docplayer.pl/24443942-Przemysl-4-0-pl-szansa-czy -zagrozenie-dla-rozwoju-innowacyjnej-gospodarki.html (accessed: 8.01.2020). 
implementation of 4.0 technology actually requires from them. New technologies can generate equally high levels of enthusiasm and fear. This ambivalence is defined in the literature as technophobia (rejection and/or avoidance of technology) and technophilia (enthusiastic absorption of technology) ${ }^{15}$.

Despite the fact that technophobia and technophilia are increasingly common phenomena, they have, so far, been studied to a limited extent due to the fact that science is increasingly focused on the development of the new technologies rather than assessing the attitudes and behaviour of their direct users. This attitude can also be said to be true of companies towards digital transformation. With this in mind, the combination of simultaneously-occurring factors that hinder the process of business reorientation may contribute to a multi-layered fear of transformation. Therefore, when companies see the scope of the concept of Industry 4.0 , they react in this way has been defined as technological anxiety, a response which may have its origins both in the enterprise's internal processes and its environment ${ }^{16}$.

Negative phenomena, mechanisms and trends observed in companies in the process of implementation and integration of technologies, machines and people may take on pathological characteristics. This organizational pathology may manifest itself, in particular, in the persistence of dysfunctions which stops the organization from achieving its goals ${ }^{17}$, and may result in wasting the potential of implementing the solutions of Industry 4.0.

\section{Dimensions of technological anxiety}

Companies seeking digital transformation should consider a number of key questions that will help narrow down the choice of the right pathway. These include which processes need to be transformed, which areas their resources should be invested in and which advanced technologies can best meet their strategic needs. This transformation process does not end with the implementation of new technologies

15 See e.g. M.E. Osiceanu, Psychological implications of modern technologies: "technofobia" versus "technophilia", "Procedia - Social and Behavioral Sciences" 2015, no. 180, pp. 1137-1144; O.Y. Khasawneh, Technophobia without boarders: The influence of technophobia and emotional intelligence on technology acceptance and the moderating influence of organizational climate, "Computers in Human Behavior" 2018, no. 88, pp. 210-218.

16 M. Młody, Lęk technologiczny...

17 R. Stocki, Diagnoza organizacji od A do Z: praktyczny podręcznik diagnozy dla konsultantów, trenerów i menedżerów, Oficyna a Wolters Kluwer business, Warszawa 2013, p. 49; C. McMillan, J. Overall, Wicked problems: turning strategic management upside down, "Journal of Business Strategy" 2016, vol. 37(1), pp. 34-43. 
as it has profound implications for the organization in terms of strategy, business model, the way the company is organized and even talent management ${ }^{18}$.

The multifaceted nature of the transformation indicates the necessity of systemic thinking, all the more so because every comprehensive, costly and long-term undertaking (such as the implementation of Industry 4.0 solutions) may expose the company's weaknesses due to the emergence of conditions unforeseen at the beginning of the transformation process. As justified earlier, companies in the process of digital transformation should not only focus on potential benefits, but, in particular, identify and analyse barriers, the elimination of which will reduce the level of technological anxiety and, consequently, also the risk of investment.

Młody ${ }^{19}$, on the basis of a review of scientific literature and studies of consulting companies and industry institutions (e.g. BCG, McKinsey, PwC, Smart Industry Polska), classified the basic internal sources and manifestations of technological anxiety, dividing them into 5 main dimensions (Figure 1): strategic planning, processes within the organization, change potential, standards and security and human resources. This division results from the nature and importance of particular factors for particular areas of a company's internal aspects of the digital transformation.

For the purposes of the research, the authors decided to extend the list with a sixth dimension - external barriers, which consists of ${ }^{20}$ :

- lack of support from the state (including e.g. investment incentives, beneficial tax solutions, reduction of bureaucracy, creation of cooperation platforms, facilitation of cooperation with scientific entities, financing of investments using 4.0 solutions and technologies);

- lack of support from local government units (conducting a range of stimulation activities, support for education, financing of investments using 4.0 solutions and technologies) and

- lack of support from industry institutions (supporting digital transformation in companies).

18 F. Hecklau et al., Holistic approach for human resource management in Industry 4.0, "Procedia CIRP” 2016, no. 54, pp. 1-6.

19 M. Młody, Lęk technologiczny...

20 See e.g. Ministry of Development, Strategia na rzecz Odpowiedzialnego Rozwoju do roku 2020 (z perspektywq do 2030 r.), Ministerstwo Rozwoju - Departament Strategii Rozwoju, Warszawa 2017; B. Michałowski, M. Jarzynowski, P. Pacek, Szanse i wyzwania polskiego przemystu 4.0, Agencja Rozwoju Przemystu, Warszawa 2018; Przemyst 4.0. Na jakim etapie przemystowej rewolucji znajduje się województwo wielkopolskie?, Wielkopolskie Regionalne Obserwatorium Terytorialne, Poznań 2019. 


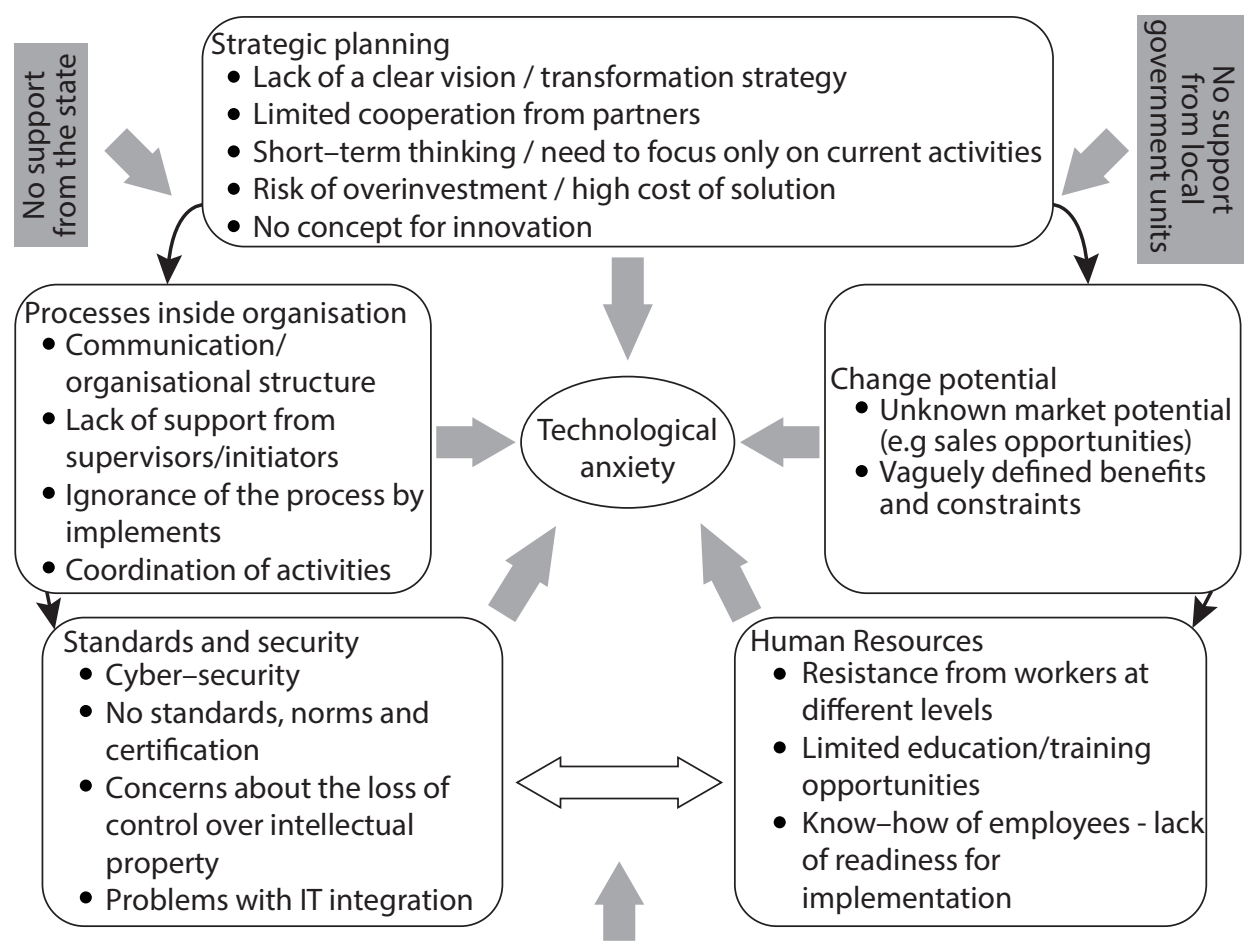

No support from industrial associations/institutions

Figure 1. Dimensions and manifestations of companies' technological anxiety related to the digital transformation

Source: elaboration based on M. Młody, Lęk technologiczny jako patologia organizacyjna w dobie czwartej rewolucji przemysłowej, "Studia i Prace Kolegium Zarządzania i Finansów” 2019, no. 175, p. 137.

A multifaceted look at the internal and external sources of technological anxiety enables a holistic analysis of this problem. Previous studies into Industry 4.0 indicate that companies have a greater awareness of the financial barriers than they do of non-financial ones ${ }^{21}$. This may change as the subsequent transformation phases pass from assessing the possibilities of actions, through the planning stage, then pilot projects, and ending with full implementation. As indicated by Schulte ${ }^{22}$, the implementation of pilot stages is a major challenge for many companies and not every pilot project is able to meet an enterprise's expectations, which means that the number of organizations implementing Industry 4.0 projects is not growing

21 Smart Industry Polska, Adaptacja innowacji w dziatalności mikro oraz małych i średnich przedsiębiorstw produkcyjnych w Polsce. Raport z badań, Ministerstwo Rozwoju/Siemens Sp. z o.o., Warszawa 2017.

22 M.A. Schulte, Digital Transformation in the Manufacturing Industry, IDC White Paper, Frankfurt am Main 2016. 
dynamically. This may suggest that, at this early stage, technological anxiety manifests itself in a specific way. New technologies and solutions should help in achieving corporate goals, but their implementation cannot be an end in itself. Promising pilot projects should be rapidly scaled up, and unsuccessful ones scrapped. Therefore, it is necessary for an organization to be prepared to take risks while fully understanding all the dimensions that cause technological anxiety.

In addition, current research suggests that it is easier to introduce 4.0 technology in a new production plant than to replace outdated solutions in an existing one ${ }^{23}$. This is related to the return on investment and the priorities set by the given organization. A company with the goal of sustainable development will be more likely to invest in solutions that bring long-term benefits.

Available studies also indicate certain differences between the SME sector and large manufacturing companies ${ }^{24}$. For large producers constant manufacturing optimisation is a typical element of process management, thereby achieving economies of scale. In the SME sector, however, the degree of manual and hybrid activities is much higher ${ }^{25}$. The relatively fewer resources (human, financial, relational) of SMEs may limit the possibility to analyse the potential effects of implementing innovative solutions, and, to a greater degree, the creation of a comprehensive technological transformation strategy.

The above considerations allow the adoption of the following research hypotheses:

H1: Companies in different phases of digital transformation are characterised by different levels of importance of technological anxiety for digital transformation.

$\mathrm{H} 2$ : Companies of different sizes, expressed in terms of employment, differ in the level of importance of technological anxiety for digital transformation.

H3: Companies differ in the level of importance of technological anxiety for digital transformation when their establishment in the market is considered.

23 Polish Industry 4.0. Raport specjalny, "Magazyn Gospodarczy Nowy Przemyst”, 2018, https:// przemysl-40.pl/wp-content/uploads/2018-Raport-Expo.pdf (accessed: 10.01.2020).

24 Smart Industry Polska, Adaptacja innowacji...

25 L. Forstner, M. Dümmler, Integrierte Wertschöpfungsnetz-werke - Chancen und Potenziale durch Industrie 4.0, "Elektrotechnik \& Informationstechnik" 2014, vol. 131(7), pp. 199-201. 


\section{Industry 4.0 in the industrial processing sector}

Industry 4.0 technologies are accelerators of the unprecedented changes observed within the ecosystems of entire industries ${ }^{26}$. Real-time data availability within a network connecting all components (e.g. machines, devices, robots, cobots, etc.) involved in creating value is crucial in the transformation process of companies.

The research results analyzed later in this article concern the industrial processing sector. Focus on this sector of the economy results from several pragmatic reasons. First of all, it is a sector of the economy responsible for a significant percentage of Polish and EU GDP27, and whose condition also affects other sectors and industries. Moreover, a visible improvement in the economic situation is signaled by manufacturing companies ${ }^{28}$. Secondly, this sector is amongst those in which the largest number of SMEs is being created and which is still growing relatively quickly ${ }^{29}$. Thirdly, it is a sector that is highly accommodating to the impact of those new 4.0 technologies that fundamentally change the rules of competition. In addition, work on developing the concept of Industry 4.0 was initially conducted with industrial manufacturing in mind ${ }^{30}$. The potential of the economy in terms of the development possibilities of Industry 4.0 can be measured using various indicators ${ }^{31}$, taking into account selected criteria, e.g. Internet accessibility and its speed, the level and state of the digitization of the business, and accessibility to highly specialized employees on the labor market and their level of education. In these rankings, Poland is placed alongside other CEE countries, while still being a significant distance behind highly developed economies (e.g. US, South Korea, Japan, Germany). For some technologies, e.g. robotics, the difference in the level of transformation is particularly evident - in Polish industrial processing there are 42 robots per 10,000 employees, 338 robots in Germany, 135 in the Czech Republic and 84 in Hungary, while the global average is 99 robots $^{32}$. It is worth pointing out, however, that the level of computerization of companies in Poland expressed by implemented IT systems supporting management (ERP

26 J. Hagel et al., From exponential technologies to exponential innovation, Deloitte Insights, 2013, https://www2.deloitte.com/us/en/insights/industry/technology/from-exponential -technologies-to-exponential-innovation.html (accessed: 12.01.2020).

27 Eurostat, Industrial production statistics, 2018, https://ec.europa.eu/eurostat/statistics-ex plained/index.php/Industrial_production_statistics (accessed: 10.01.2020).

28 GUS, "Biuletyn statystyczny" 2019, nr 03.

29 PARP, Raport o stanie sektora matych i średnich przedsiębiorstw w Polsce, Grupa PFR, Warszawa 2019, https://www.parp.gov.pl/storage/publications/pdf/2019_07_ROSS.pdf (accessed: 11.01.2020).

30 A. Issa et al., Industrie 4.0 roadmap...

31 E.g. NRI, DESI, EDPR; B. Michałowski, M. Jarzynowski, P. Pacek, Szanse i wyzwania...

32 IFR, World Robotics Industrial Robots International Federation of Robotics, 2019. 
and CRM classes) is growing year by year ${ }^{33}$. Moreover, ever more companies are using a variety of ICTs that increase the potential for information support in management processes $^{34}$ and also contribute to the development of the concept of Industry 4.0.

Regardless of the indicators analyzed, Industry 4.0 is seen as an opportunity for more rapid development of companies. In particular, the industrial processing sector is accommodating to changes, as part of which one can observe the progressive integration of ICT, robotics and automation, affecting the optimization of production processes, and thus strengthening the competitive position.

\section{Research Methodology}

\section{Scope of research}

The research was conducted among company owners, board members, CEOs, executive directors, strategic directors and managing directors who decided on the future directions of companies' development. The respondents represented manufacturing companies from the industrial processing sector whose business activities are conducted in Poland. The study was conducted in the third quarter of 2019.

\section{Research instrument and data analysis methods}

The electronic questionnaire had the option of being filled in on-line (through: https://strategicznie.pl/). The study was based on this closed data collection. The EMIS Professional database was used as a sampling frame. The database was used to access the list of current companies (the surveyed population) with contact details (email address). Invitations to participate in the study were sent by e-mail.

The obtained empirical data were analyzed statistically by presenting distributions of the studied variables in tabular or graphical form and determining the structure, intensity and measures of descriptive statistics ${ }^{35}$. A method of analysis of the summary data of statistical measures was applied, the average intensity level was compared using the Student t-test for independent samples and analysis of variance (ANOVA) was carried out.

33 A. Weinert, Zaawansowanie przedsiębiorstw w zakresie informacyjnego wspomagania wyborów strategicznych, Uniwersytet Ekonomiczny w Poznaniu, Poznań 2018.

34 GUS, Społeczeństwo informacyjne w Polsce w 2017 roku, Warszawa 2017, http://stat.gov.pl/ob szary-tematyczne/nauka-i-technika-spoleczenstwo-informacyjne/spoleczenstwo-informa cyjne/spoleczenstwo-informacyjne-w-polsce-w-2017-roku,2,7.html (accessed: 12.01.2020). IBM SPSS (version 21) was used for data analysis. 


\section{Characteristics of the research sample}

A total of 120 completed questionnaires was obtained. The research sample included companies from the industrial processing sector, belonging, according to the PKD (Code list of classification of business activities in Poland), to the following sectors: electrical equipment $-23 \%$, foodstuffs $-19 \%$, machinery and equipment not classified elsewhere $-10 \%$, chemicals and chemical products $-6 \%$, furniture $-6 \%$, computers, electrical and optical products $-5 \%$, clothing $-4 \%$, metals $-4 \%$, beverages $-3 \%$ and other sectors of the PKD $(16,17,18,22,23,29,33)-20 \%$. The comparison of the population structure and the examined sample of companies showed structural differences in particular sections ${ }^{36}$. The selection was therefore ultimately disproportionate. The surveyed companies were business entities employing: less than 50 persons (40\%), from 50 to 249 employees (38\%), more than 250 employees (22\%), as well as with different sources of capital (exclusively Polish capital $-75 \%$, mixed capital - 13\%, exclusively foreign capital - 12\%) and the age of the enterprise (established before 1989 - 34\%; established in the years 1989-2004 - 38\%; established after $2004-28 \%$ ).

\section{Results of Empirical Research}

\section{Industry 4.0 in companies of the Polish industrial processing sector}

The first area of research proceedings was the assessment of the level of implementation of Industry 4.0 solutions and the scope of its knowledge in manufacturing companies in the Polish industrial processing sector.

According to the obtained results, more than half of the companies (52\%) have either already implemented some solutions characteristic for the fourth industrial revolution or plan to start the process of digital transformation in the medium term (less than 5 years) ${ }^{37}$. It is also worth mentioning that in most of the surveyed companies the resultant implementations of these technologies are assessed positively.

On the other hand, the level of knowledge of the concept of Industry 4.0 among the managerial staff in the surveyed companies is relatively low. Awareness of the assumptions of the new industrial revolution is acknowledged by only $25 \%$ of strategic

36 GUS, Zmiany strukturalne grup podmiotów gospodarki narodowej w rejestrze REGON, I pótrocze 2018 roku, Warszawa 2019.

37 Scale used: revolution initiated, planned revolution (in 5 years and less), planned revolution (more than 5 years), revolution not taken into account. 
managers (excellent knowledge 5\% and good 20\%). The majority of those surveyed assess their level of knowledge as insignificant (60\%) (very weak and weak), which raises some concerns about the progress of the implementation of this technology in companies and the likelihood of its rapid development in the Polish industrial processing sector. To a certain extent this is also confirmed by the results concerning the sources of information accessed on the concept of the Revolution 4.0. In the surveyed companies it is mostly press articles/Internet/radio/television (as much as $66 \%$ ). The respondents more rarely indicate workshops/training (internal and external) (19\%), postgraduate studies and MBA (7.5\%). However, it is worth noting the importance of the knowledge and information obtained from manufacturers and suppliers of 4.0 machines and technologies, as well as from the organisers of trade fairs (8\%), who offer numerous new solutions to improve the production of companies in the fourth industrial revolution.

Taking into account the publicity that the concept of Industry 4.0 is gaining in scientific literature, business practice and at the political level, a reflection arises on the role of the mass media in education, as well as on the approach of entrepreneurs and managers to broadening their knowledge about the concept of 4.0 technology and digital transformation.

\section{Barriers and obstacles to digital transformation in the surveyed companies}

The next step in the research process was to assess the level of importance of technological anxiety for the digital transformation of companies. As indicated earlier, eliminating associated barriers and obstacles is one of the challenges facing managers of manufacturing companies in the Polish industrial processing sector.

Twenty-one variables were assessed (factors concerning the total number of barriers and obstacles to digital transformation), whose significance was presented in terms of six dimensions of technological anxiety. For each of them, the average level of significance was presented according to the particular concerns shown by the surveyed companies (Figure 2). Among the responses of strategic managers, concerns common for the functioning and management of the enterprise are particularly noticeable. Empirical results allow one to prioritise the identified barriers and obstacles to the digital transformation of the surveyed companies. The respondents replies reveal that the most significant factors include the high costs of 4.0 solutions (overinvestment fear) $(\bar{x}=3.93)$, lack of knowledge about 4.0 machine and the technology implementation process $(\bar{x}=3.81)$, resistance of employees at various organizational levels $(\bar{x}=3.75)$, the issue of ensuring cyber-security/data protection $(\bar{x}=3.75)$, the imprecisely defined benefits and limitations 
of implementation $(\bar{x}=3.70)$ and slow coordination of implementation activities $(\bar{x}=3.70)$. For the remaining variables, the obtained values are below $\bar{x}=3.7$, but remain at a level higher than moderate, which indicates their relatively common occurrence in the surveyed companies.

Looking at the results obtained from the point of view of particular dimensions, it should be noted that not one of them is distinguished by its level of low/high significance, except for external barriers (lack of support from the state, territorial/ local government units and industrial institutions), where none of the factors exceeded the average of 3.5. In the case of the remaining dimensions, the significance of the particular factors varies.

\section{Factors (barriers and obstacles)}

1. Lack of a clear vision/transformation strategy

2. Limited cooperation from partners

3. Short-term thinking

4. Risk of overinvestment/high cost of solution

5. No concept for innovation

6. Communication/organisational structure

7 Lack of support from supervisors/initiators

8 Ignorance of the process by implementers

9. Coordination of activities

10. Unknown market potential

11. Vaguely defined benefits and constraints

12. Cyber-security/data protection

13. No standards, norms and certification

14. Concerns about the loss of intellectual property

15. Problems with IT integration

16. Know-how of employees - no readiness to implment

17. Limited education/training opportunities

18. Resistance from workers at different levels

19. No support from the State

20. No support from professional institutions

21. No support from territorial self-government units

* The Likert scale (five-point): 1 - low importance, 2 - slightly important, 3 - neutral, 4 - moderately important, 5 - very important.

Figure 2. Mean level of importance of factors concerning technological anxiety for digital transformation in the analysed companies $(N=120)$

Source: own elaboration.
Anxiety dimension

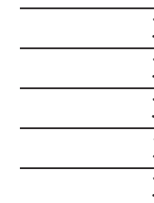

3,37

$3,40-$ Internal

$3,56 \longrightarrow$ processes

$3,81\}$ of organisation

3,70

3,67 Change

potential

3,41
3,43 $\Rightarrow \begin{array}{r}\text { Standards } \\ \text { and security }\end{array}$

3,41
3,43 $\Rightarrow \begin{gathered}\text { Standards } \\ \text { and security }\end{gathered}$

HR

External

barriers

Strategic
planning

3,70

3,61

$3,43>\mathrm{HR}$

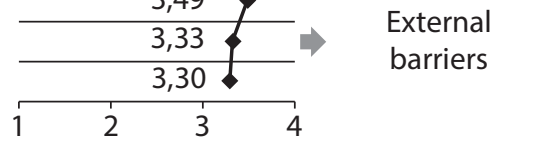

\begin{tabular}{ll|l|l|}
\hline & 3,75 & \\
3,49 & \\
\hline & 3,33 & \\
\hline & 3,30 & \\
\hline 2 & 3 & 4
\end{tabular}


The obtained results imply that the identified barriers and obstacles to digital transformation may have a negative impact on the reorientation process of manufacturing companies from the industrial processing sector. However, it is impossible to assess on the basis of the obtained results whether and to what extent the individual factors interact with each other, strengthen each other or lead to the creation of further barriers. More broadly, these restrictions may also have a cross-sectoral impact, hindering the development of the economy 4.0. In this context, it is worth restating the insufficient level of knowledge and implementation skills in the surveyed companies with regard to the applied solutions of Revolution 4.0.

\section{Comparison of the significance of technological anxiety between the sets of the surveyed companies}

The final stage of the research procedure was to compare the mean values (significance) of the barriers and obstacles to the digital transformation due to the characteristics of the companies involved. This was done using the t-test for independent groups and the single-factor method ANOVA ${ }^{38}$.

First, differentiation of the significance of identified concerns in the set of companies was verified with regard to the phase of the digital transformation process (Table 1).

Table 1. Comparison of the importance of technological anxiety in the surveyed companies in terms of the phases of the digital transformation process

\begin{tabular}{|l|c|c|c|c|}
\hline \multirow{2}{*}{ Factor } & \multicolumn{2}{|c|}{ Digital transformation } & \multirow{2}{*}{ ANOVA F/p } \\
\cline { 2 - 5 } & $\begin{array}{c}\text { Not launched } \\
\text { (and unplanned) }\end{array}$ & Planned & Launched & \multirow{2}{*}{ Lan } \\
\hline (12) cyber-security/data protection & 3.52 & 3.65 & 4.22 & $3.190^{\star}$ \\
\hline (15) problems with IT integration & 3.04 & 3.68 & 3.70 & $4.998^{\star *}$ \\
\hline
\end{tabular}

$p$ - significance level; ${ }^{\star} p \leq 0.05 ;{ }^{\star \star} p \leq 0.01$.

Source: own elaboration.

The results obtained indicate two factors, the importance of which was different in the company sets. It should be noted that the importance of cyber-security and IT integration problems is always higher in companies that have started their digital transformation than in companies planning changes or not starting to change. At the same time, companies that do not plan to make the digital transformation are less affected by these concerns, which seems justified.

38 Presentation of the results in the article is limited to the presentation of those for which the methods used allowed for the identification of statistically significant differences between the analysed companies. 
The next step was to verify the importance of technological anxiety in the companies due to the size of the entity in terms of employment levels (Table 2).

Table 2. Comparison of the significance of technological anxiety in the surveyed companies in terms of size of employment

\begin{tabular}{|c|c|c|c|c|}
\hline \multirow{2}{*}{ Factor } & \multicolumn{3}{|c|}{ Company size (by employment) } & \multirow{2}{*}{$\begin{array}{c}\text { ANOVA } \\
\text { F/p }\end{array}$} \\
\hline & Small & Middle & Large & \\
\hline (4) risk of overinvestment - high cost of solution & 4.36 & 3.68 & 3.74 & $5.933^{*}$ \\
\hline (17) limited education/training opportunities & 3.61 & 3.52 & 2.96 & $3.974^{\star}$ \\
\hline (19) no State support & 3.86 & 3.45 & 2.96 & $4.580^{*}$ \\
\hline (20) no support from professional institutions & 3.61 & 3.41 & 2.74 & $6.362^{\star \star}$ \\
\hline (21) no support from local government units & 3.67 & 3.25 & 2.83 & $4.028^{\star}$ \\
\hline
\end{tabular}

$p$ - significance level; * $p \leq 0.05 ;{ }^{* *} p \leq 0.01$.

Source: own elaboration.

The research results indicate that the importance of technological anxiety for five factors, varies according to the size of the company (expressed by employment level). A general trend can be observed that the importance of the identified barriers and obstacles to the digital transformation decreases as the size of the enterprise increases. The greatest importance of concerns was observed for each variable in small companies.

The comparison of the average significance of technological anxiety in companies when the age of the surveyed entities is considered allowed for the identification of two statistically significant differences in the set of factors (Table 3 ).

Table 3. Comparison of the significance of technological anxiety in the surveyed companies in terms of their age (the year of establishment)

\begin{tabular}{|c|c|c|c|c|}
\hline \multirow[b]{2}{*}{ Factor } & \multicolumn{3}{|c|}{ Company age } & \multirow[b]{2}{*}{$\begin{array}{l}\text { ANOVA } \\
\mathrm{F} / \mathrm{p}\end{array}$} \\
\hline & $\begin{array}{l}\text { Established } \\
\text { before } 1989\end{array}$ & $\begin{array}{l}\text { Established } \\
\text { in the years } \\
1989-2004\end{array}$ & $\begin{array}{l}\text { Established after } \\
2004\end{array}$ & \\
\hline (19) no State support & 3.08 & 3.81 & 3.63 & $4.334^{\star}$ \\
\hline $\begin{array}{l}\text { (21) no support from } \\
\text { local government units }\end{array}$ & 2.95 & 3.57 & 3.44 & $3.143^{\star}$ \\
\hline
\end{tabular}

$p$ - significance level; ${ }^{\star} p \leq 0.05$.

Source: own elaboration.

The results presented in Table 3 show a differentiation in the importance of barriers and obstacles to digital transformation. At the same time, it can be seen that for "older" companies, the importance of these concerns is always lower. 


\section{Discussion and summary}

The results show that the industrial processing sector in Poland notice the many threats during their digital transformation process. Factors related to costs and lack of awareness of solutions available on the market are of primary importance. Although significant barriers and obstacles in the process of transformation of companies in the Polish industrial processing sector do exist, their perceived level of importance as well as the whole premise of technological anxiety may result not only from real and rational premises, but also from the lack of knowledge in this respect among both strategic managers and lower-level employees. The fears indicated, combined with the low level of knowledge of the concept of Industry 4.0, certainly result in difficulties in choosing the right path for the digital transformation of manufacturing companies in the industrial processing sector. Thus, it would be intriguing to know what barriers and obstacles that lead to technological anxiety hamper the transformation of companies in other sectors.

As a result of the conducted research, statistically substantial differences in the significance of particular components of technological anxiety for digital transformation in the surveyed companies were indicated for the following categories: phase of the digital transformation process, size of the company and age of the company. The obtained empirical results allow for a partial positive verification of the research hypotheses in terms of statistically significant differences found, according to which companies:

- in different phases of digital transformation processes are characterised by different levels of anxiety over ensuring cyber-security, data protection and IT integration $\left(\mathrm{H}_{1}\right)$;

- characterised by different employment size, differ in the level of importance of anxiety in relation to the high costs of implementing 4.0 solutions; education and training opportunities, and lack of support from the State, industry institutions and local government units (external barriers) $\left(\mathrm{H}_{2}\right)$;

- characterised by their date of establishment on the market (the age of the company) differ in the level of anxiety in relation to lack of support from the State and local government units (external barriers) $\left(\mathrm{H}_{3}\right)$.

In addition, interesting regularities can be observed on the basis of the results obtained, which we attempted to justify below.

Firstly, companies that have started or plan to start the digital transformation are characterised by their higher level of concerns regarding cyber security, data protection and IT integration problems. This may be due to the fact that these companies, already in the deployment phase of certain technologies (e.g. ICT), are 
more aware of the problems and barriers that may arise in this process ${ }^{39}$. Experience in this case may have a negative impact on the perception of barriers related to the 'standards and security' dimension.

Secondly, larger companies concur with regard to their lower concerns over the high cost of solutions and the limited education/training opportunities, as well as support from the state, industry institutions and local government units. The lower importance of costs and possible risks of overinvestment ("strategic planning" dimension) and the possibility of further training of employees may have its significance in the greater independence of large companies - in terms of investment capital and development opportunities (their wide range of internal and external training, individual development programmes, career paths, etc. ${ }^{40}$. Small companies are much more vulnerable to economic fluctuations in this area.

Thirdly, companies established before 1989 have a lower level of concerns regarding support from the state and local government units. This may indicate a greater resilience of these companies to strategic changes, including a reorientation towards the economy 4.0. This outcome (indicated by a detailed analysis of respondents' answers) may result from the fact that a significant number of companies established in this period belongs to the group of medium and large companies, which, in turn, may make them more independent in terms of their investments. The presence of enterprises with State Treasury participation in this group also seems to be crucial, a fact which may influence the relatively positive perception of the indicated external barriers.

\section{Managerial implications}

The fears of companies, combined with a low level of knowledge of the Industry 4.0 concept, may result in difficulties in choosing the right path of transformation. Technological anxiety becomes pathological when it begins to dominate the behaviour of management, and, consequently, the functioning of companies in the era of the fourth industrial revolution. It significantly complicates the strategic choices and limits the freedom of investment and adaptation activities, which may lead to long-term disturbances in economic operations This anxiety leads to companies

39 See e.g. L. Arendt, Barriers to ICT adoption in SMEs: how to bridge the digital divide?, "Journal of Systems and Information Technology" 2008, vol. 10(2), pp. 93-108; V. Parida et al., Barriers to information and communication technology adoption in small firms. Past experiences, current knowledge and policy implication, Working paper, Swedish Entrepreneurship Forum, Stockholm 2010.

40 PKO BP, Rynek usług szkoleniowych. Monitoring branżowy, 2016, http://www.pkobp.pl/media _files/6df66082-489e-441f-9413-f66a726c945b.pdf (accessed: 10.01.2020). 
desisting with the changes associated with Industry 4.0, a choice which is disproportionate to the actual degree of risk.

In order to become competitive, the Polish industrial processing sector must undertake investments in modern technologies. From this point of view, the dimensions of technological anxiety diagnosed in the study are crucial, as they concern challenges and obstacles observed at each level of the organization. The identification, analysis and assessment of areas of technological anxiety should be treated as a starting point in the process of implementation of Industry 4.0 solutions. This phase should even precede the identification and assessment of opportunities, the implementation plan and full deployment. The indicated list of negative aspects related to the process of digital transformation may, at the same time, constitute grounds for a diagnosis by the enterprise, on the basis of which appropriate preventive, corrective or adaptive actions may be introduced.

\section{Limitations and directions of further research}

The quantitative study carried out has its limitations. Firstly, the size of the research sample does not allow for a generalisation of results for the whole sector of industrial processing in Poland due to the lack of entities representing all sections. Secondly, it should be remembered that the answers obtained are of a declarative nature. Thirdly, the presented model's approach to technological anxiety cannot be treated as static due to the probable evolution of technology 4.0 itself and solutions to the issues of its implementation in a way that is not currently anticipated ${ }^{41}$. The deployment and use of 4.0 machines and technology by businesses effecting digital transformation may face barriers and obstacles that have not been foreseen.

Analysis and assessment of technological anxiety should be systemic in nature. The research approach covering selective identification of the ground of non-implemented transformation or slow implementation of modern technologies would be inconsistent with the essentially holistic nature of the Industry 4.0 concept. In this context, the presented results may constitute empirical material for further research work. In particular, it seems crucial to identify the sources and patterns of the emergence of the phenomena that form the particular dimensions of technological anxiety, which would enable a definition of preventive actions necessary. Obtaining more detailed conclusions on the significance of particular dimensions of technological anxiety for the digital transformation of companies would be possible on the basis of qualitative research carried out, in particular, among

41 Deloitte, The Industry 4.0 paradox: Overcoming disconnects on the path to digital transformation, Deloitte Development LLC, 2018, https://www2.deloitte.com/global/en/pages/energy -and-resources/articles/the-industry-4-0-paradox.html (accessed: 8.01.2020). 
companies which have successfully implemented and integrated technologies of Industry 4.0. It also seems desirable to develop tools for measuring technological anxiety and, subsequently, to understand the threshold between the natural fear of new solutions and technologies and pathological anxiety. One possible approach to analysing the problem of technological anxiety could be the use of so-called resistance indicators ${ }^{42}$. In the current, extremely turbulent and dynamic economic reality, research may contribute to a greater understanding of the conditions for the effective implementation of the solutions of the Industry 4.0 concept, as well as contribute to the faster development of businesses in Poland.

\section{References}

Alcácer V., Cruz-Machado V., Scanning the Industry 4.0: A Literature Review on Technologies for Manufacturing Systems, "Engineering Science and Technology an International Journal" 2019, vol. 22(3), pp. 899-919.

Allende M.M., Ruiz-Martina C., Lopez-Paredesa A., Ríosa J.M.P., Aligning Organizational Pathologies and Organizational Resilience Indicators, "International Journal of Production Management and Engineering" 2017, vol. 5(2), pp. 107-116.

Arendt L., Barriers to ICT adoption in SMEs: how to bridge the digital divide?, "Journal of Systems and Information Technology" 2008, vol. 10(2), pp. 93-108.

BCG, Przemyst 4.0 PL. Szansa czy zagrożenie dla rozwoju innowacyjnej gospodarki?, Boston Consulting Group, Boston 2016, https://docplayer.pl/24443942-Przemysl-4-0-pl-szansa-czy -zagrozenie-dla-rozwoju-innowacyjnej-gospodarki.html (accessed: 8.01.2020).

Deloitte, The Industry 4.0 paradox: Overcoming disconnects on the path to digital transformation, Deloitte Development LLC, 2018, https://www2.deloitte.com/global/en/pages/energy-and -resources/articles/the-industry-4-0-paradox.html (accessed: 8.01.2020).

Eurostat, Industrial production statistics, 2018, https://ec.europa.eu/eurostat/statistics-expla ined/index.php/Industrial_production_statistics (accessed: 10.01.2020).

Forstner L., Dümmler M., Integrierte Wertschöpfungsnetz-werke - Chancen und Potenziale durch Industrie 4.0, "Elektrotechnik \& Informationstechnik" 2014, vol. 131(7), pp. 199-201.

GUS, "Biuletyn statystyczny" 2019, nr 03.

GUS, Społeczeństwo informacyjne w Polsce w 2017 roku, Warszawa 2017, http://stat.gov.pl/obsza ry-tematyczne/nauka-i-technika-spoleczenstwo-informacyjne/spoleczenstwo-informacy jne/spoleczenstwo-informacyjne-w-polsce-w-2017-roku,2,7.html (accessed: 12.01.2020).

GUS, Zmiany strukturalne grup podmiotów gospodarki narodowej w rejestrze REGON, I pótrocze 2018 roku, Warszawa 2019.

Hagel J., Brown J.S., Samoylova T., Lui M., From exponential technologies to exponential innovation, Deloitte Insights, 2013, https://www2.deloitte.com/us/en/insights/industry/technolo gy/from-exponential-technologies-to-exponential-innovation.html (accessed: 12.01.2020).

Hecklau F., Galeitzke M., Flachs S., Kohl H., Holistic approach for human resource management in Industry 4.0, "Procedia CIRP" 2016, no. 54, pp. 1-6.

42 M.M. Allende et al., Aligning Organizational Pathologies and Organizational Resilience Indicators, "International Journal of Production Management and Engineering" 2017, vol. 5(2), pp. 107-116. 
Herbert L., Digital Transformation: Build Your Organization's Future for the Innovation Age, Bloomsbury, London 2017.

Horváth D., Szabó R., Driving forces and barriers of Industry 4.0: Do multinational and small and medium-sized companies have equal opportunities?, "Technological Forecasting and Social Change" 2019, vol. 146(C), pp. 119-132.

IFR, World Robotics Industrial Robots International Federation of Robotics, 2019.

Issa A., Hatiboglu B., Bildstein A., Bauernhansl T., Industrie 4.0 roadmap: Framework for digital transformation based on the concepts of capability maturity and alignment, "Procedia CIRP" 2019, no. 72, pp. 973-978.

Kang H.S., Lee J.Y., Choi S., Kim H., Park J.H., Son J.Y., Kim B.H., Do Noh S., Smart manufacturing: past research, present findings, and future directions, "International Journal of Precision Engineering and Manufacturing - Green Technology" 2016, vol. 3(1), pp. 111-128.

Khasawneh O.Y., Technophobia without boarders: The influence of technophobia and emotional intelligence on technology acceptance and the moderating influence of organizational climate, "Computers in Human Behavior" 2018, no. 88, pp. 210-218.

Klingenberg C.O., Borges M.A.V., Antunes Jr. J.A.V., Industry 4.0 as a data-driven paradigm: a systematic literature review on technologies, "Journal of Manufacturing Technology Management" 2019, http://doi.org/10.1108/jmtm-09-2018-0325

Martínez-Corcoles M., Teichmann M., Murdvee M., Assessing technophobia and technophilia: Development and validation of a questionnaire, "Technology in Society" 2017, no. 51, pp. 183-188.

McKinsey, Industry 4.0. Capturing value at scale in discrete manufacturing, 2016, https://www.mc kinsey.com (accessed: 8.01.2020).

McMillan C., Overall J., Wicked problems: turning strategic management upside down, "Journal of Business Strategy" 2016, vol. 37(1), pp. 34-43.

Michałowski B., Jarzynowski M., Pacek P., Szanse i wyzwania polskiego przemystu 4.0, Agencja Rozwoju Przemystu, Warszawa 2018.

Ministry of Development, Strategia na rzecz Odpowiedzialnego Rozwoju do roku 2020 (z perspektywq do 2030 r.), Ministerstwo Rozwoju - Departament Strategii Rozwoju, Warszawa 2017.

Młody M., Lęk technologiczny jako patologia organizacyjna w dobie czwartej rewolucji przemystowej, "Studia i Prace Kolegium Zarządzania i Finansów” 2019, no. 175, pp. 129-144.

Mtody M., Weinert A., Industry 4.0 in Poland: A Systematic Literature Review and Future Research Directions, [in:] A. Zakrzewska-Bielawska, I. Staniec (eds), Contemporary Challenges in Cooperation and Coopetition in the Age of Industry 4.0: 10th Conference on Management of Organizations' Development (MOD), Springer International Publishing, Cham 2020, pp. 43-71, http://doi.org/10.1007/978-3-030-30549-9_2

Müller J.M., Industry 4.0 in the Context of the Triple Bottom Line of Sustainability: A Systematic Literature Review, [in:] C. Silvestri, M. Piccarozzi, B. Aquilani (eds), Customer Satisfaction and Sustainability Initiatives in the Fourth Industrial Revolution, IGI Global, Hershey 2020, pp. 1-20, http://doi.org/10.4018/978-1-7998-1419-1 (accessed: 8.01.2020).

Nosalska K., Piątek Z., Mazurek G., Rządca R., Industry 4.0: coherent definition framework with technological and organizational interdependencies, "Journal of Manufacturing Technology Management” 2019, https://doi.org/10.1108/JMTM-08-2018-0238 (accessed: 8.01.2020).

Osiceanu M.E., Psychological implications of modern technologies: "technofobia" versus "technophilia", "Procedia - Social and Behavioral Sciences" 2015, no. 180, pp. 1137-1144.

Parida V., Johansson J., Ylinenpää H., Baunerhjelm P., Barriers to information and communication technology adoption in small firms. Past experiences, current knowledge and policy implication, Working paper, Swedish Entrepreneurship Forum, Stockholm 2010. 
PARP, Raport o stanie sektora małych i średnich przedsiębiorstw w Polsce, Grupa PFR, Warszawa 2019, https://www.parp.gov.pl/storage/publications/pdf/2019_07_ROSS.pdf (accessed: 11.01.2020).

PKO BP, Rynek usług szkoleniowych. Monitoring branżowy, 2016, http://www.pkobp.pl/media_fi les/6df66082-489e-441f-9413-f66a726c945b.pdf (accessed: 10.01.2020).

Polish Industry 4.0. Raport specjalny, "Magazyn Gospodarczy Nowy Przemyst”, 2018, https://prz emysl-40.pl/wp-content/uploads/2018-Raport-Expo.pdf (accessed: 10.01.2020).

Przemysł 4.0. Na jakim etapie przemysłowej rewolucji znajduje się województwo wielkopolskie?, Wielkopolskie Regionalne Obserwatorium Terytorialne, Poznań 2019.

PwC, Przemyst 4.0, czyli wyzwania wspótczesnej produkcji, PwC Polska, 2017, https://www.pwc .pl/pl/publikacje/2017/przemysl-4-0.html (accessed: 12.01.2020).

Schulte M.A., Digital Transformation in the Manufacturing Industry, IDC White Paper, Frankfurt am Main 2016.

Schwab K., Czwarta rewolucja przemystowa, transl. A.D. Kamińska, Wydawnictwo Studio EMKA, Warszawa 2018.

Smart Industry Polska, Adaptacja innowacji w działalności mikro oraz małych i średnich przedsiębiorstw produkcyjnych w Polsce. Raport z badań, Ministerstwo Rozwoju/Siemens Sp. z o.o., Warszawa 2017.

Stocki R., Diagnoza organizacji od A do Z: praktyczny podręcznik diagnozy dla konsultantów, trenerów i menedżerów, Oficyna a Wolters Kluwer business, Warszawa 2013.

Weinert A., Zaawansowanie przedsiębiorstw w zakresie informacyjnego wspomagania wyborów strategicznych, Uniwersytet Ekonomiczny w Poznaniu, Poznań 2018.

\section{Abstract}

The era of the fourth industrial revolution - which is gradually compelling companies to implement advanced machines and technologies and integrate such technology into the workplace, thereby creating a cyber-physical reality - brings a number of negative factors and phenomena that hinder transition. The aim of the article is to determine the significance of this technological anxiety for the digital transformation of manufacturing companies operating in the Polish industrial processing sector. The presentation of empirical results focuses on six dimensions of technological anxiety, i.e.: strategic planning, internal processes, change potential, standards and security, human resources and external barriers. The phases of their digital transformation, the level of employment, as well as the time they have been present in the market, were used as the prerequisites for differentiation across the research sample of 120 companies. The obtained results allowed for a partial verification of three research hypotheses and the indication of noticeable regularities in the examined area.

Keywords: Industry 4.0, technological anxiety, barriers, fourth industrial revolution, digital transformation, industrial processing sector, manufacturing companies 